\title{
Undergraduate Students' Ability in Writing Argumentative Essay at Universitas Negeri Padang
}

\author{
Nikmah Hayati Tanjung $^{1 *}$ and Muhammad Al Hafizh ${ }^{2}$ \\ ${ }^{12}$ English Department, FBS Universitas Negeri Padang, Sumatera Barat 21531, Indonesia \\ *Corresponding author. Email: nikmah.hayatitanjung@gmail.com
}

\begin{abstract}
Writing has a significant impact in determining students' capability and quantity in academic activities in language learning at schools or colleges. One of the essays display in English academic writing is an argumentative essay. Writing an argumentative essay leads students to explore their opinions or arguments to convince the reader. Nevertheless, some studies pointed out the students faced some difficulties in writing an argumentative essay. Firstly, the students faced challenges referred to developing and organizing ideas. Secondly, the students encountered struggles in producing solid evidence in their writing. Therefore, they still cannot write an argumentative essay clearly and convincingly. In writing a good and readable argumentative essay, some aspects that need to consider by students involve scientific arguments or ideas, rhetorical features, and convince the reader to accept their point of view in writing. The objective of this study was to find out the students' ability in writing an argumentative essay properly. This study belongs to descriptive research with a qualitative approach. The data were taken from the final test of essay writing subject written by 25 students in the third semester of the English language and Literature Department at Universitas Negeri Padang. The data have been collected through document analysis. The data were analyzed by using Reinking and Osten's (2017) theory. The research finding showed that the ability of students to write an argumentative essay was categorized as average, with a mean score of 68 . The result indicated that the students were required to improve and develop their ability to write an argumentative essay correctly and convincingly.
\end{abstract}

Keywords: Ability, argumentative essay, generic structure, writing

\section{INTRODUCTION}

Writing is the result of a thinking process that produces ideas or arguments arranged into coherent sentences and paragraphs so that the reader receives the message in written form [1]. In addition, writing leads students to expand their knowledge through grasping the meaning of the text [2]. Besides, writing is necessary for students in determining their capability and quantity in language learning as schools or colleges. It causes writing fosters students to explain and cultivate their ideas to produce some papers, essays, journals, articles, theses, and dissertations [3]. As a conclusion, writing is a way for students to explore their thoughts, feelings, and ideas toward what they have, read, seen, or experienced in written form. Then, it deals that writing is decided to be one of the productive skills of the language.

Furthermore, Nurbayani argues that one of the foundations of writing better scientific papers is improving writing skills within academic practice. Moreover, there are two bases in writing components;first, comprehending the writing process to deliver the meaning and communicate the idea into written form. Second, understanding the elements of writing involves content, structure, grammar or language use, vocabulary, and mechanics[4]. For this reason, writing ability is the process of thinking skills that explores thoughts, feelings, and pouring into sentences or text, so the reader grabs the meaning of writing.

However, writing belongs as a complicated and difficult one among the language skills [5]. In addition to knowing or understanding writing components, writing also requires a neurological, physical, and coginitive combination to compose a good writing product [6]. In brief, writing is claimed as one of the most complicated in language skills because it integrates many aspects to produce a good writing.

At the university level, particularly in the English language study program at Universitas Negeri Padang, the writing courses includes paragraph writing subject, essay writing subject, and academic writing subject. Moreover, writing an essay is one of the tasks still offered to students by lectures and is mainly used to measure comprehension and students' writing ability. Then, by writing in essay form, the students are 
expected to practice and improve their ability to communicate in writing. They also can increase their knowledge and their depth of understanding related the issues. Meanwhile, Argumentative essay is as one of the writing genres that learners face in universities. Thus, an argumentative essay is an essay that contains the writer's argument whether they agree or disagree with giving facts or evidence to strengthen the writer's opinion [7].

In line with Oshima, Permata [8] explains that argumentative essay as a complex activity in which the researchers take position on a controversial issue, giving reasons and supporting evidence to convince the reader in order to accept the writers' position. Based on the definition, an argumentative essay is an essay that provides the writer's argument is related to both sides of the controversial issue supported by evidence and convinces the reader to agree with the writer's point of view. In other words, in writing an argumentative essay, the writer attempts to assure the readers have the same standpoint related to the issue debated supported by solid reasons or evidences. The writer also provides reasons to support their point and exposes the problems from the opposite reasons as the evidence that the wruter assumes the issue is false.

An argumentative essay is organized into an introduction, body, and conclusion. The introduction describes some direct or indirect questions that might be posed, state the thesis statement, and confirm the position of the writer's argument. The body presents supporting evidence of an issue, explains how the evidence was gathered that makes it credible, and indicates how the evidence support the conclusion. A conclusion outlines reaffirm position or suggest the writer's consequence, evaluates the evidence, and concludes.[9]. Along with Reinking and Osten, Oshima [7] also stressed five points covered in writing an argumentative essay: first, explanation of the issue; second, an obvious thesis statement; third, a review of the opposing arguments; fourth, rebuttals to the opposing arguments; fifth, arguments of the writer.

In summary, writing an argumentative essay presents an argument as one of the components necessary by the writer. In addition, the argumentative essay provides some data relevant to the issues, including facts, examples, and logical ideas to support the writer's point of view. On the other hand, a writer must also defend his position and opinion by knowing the background information of the issue discussed to produce a good argumentative essay. For as much as an argumentative essay leads the reader to agree with the writer's point of view.

On the contrary, among text types in writing, an argumentative essay is one of the most difficult for students. Concerning that, based on the preliminary observation in the English language and Literature Department, students frequently encounter various challenges and difficulties in writing an argumentative essay. The students revealed they felt a problem connecting ideas, although they already have an outline of their topic. Additionally, another context is the difficulties faced by undergraduate students in writing an argumentative essay as follows; commonly, many undergraduate students are stuck in writing topic sentences. They found it challenging to provide the evidence clearly because they did not have enough background knowledge about the topic. In addition, they also explained that they had to consider the facts in writing the essay. Thus, it made them be confused with developing their argument in their writing. In addition, the students also revealed that the difficulty of writing an essay united and coherently since they lacked knowledge about rhetorical features in writing argumentative essay. Consequently, an argumentative essay still becomes an issue for EFL learner universities since students must write English essays properly.

Based on previous studies, students still encountered some difficulties in composing an argumentative essay. Kakande and Kaur [10] affirm that an argumentative essay is one of the intricate writing models. As mentioned in their research finding, students encountered some difficulties, such as difficulty organizing ideas and connecting to other arguments. Further, they also less to display the strengthen evidence, eventually their essay not well-organized. Besides, students' other challenges are insufficient knowledge related to the grammatical structure, linguistic, and structure of an argumentative essay.

Next, Japanese learners also struggle with writing an argumentative essay, notably organizing and structuring ideas. Likewise, the students determine other challenges, such as writing topic sentences and counter claims, grammar, punctuation, vocabulary, and using academic tone[11]. To summarize, the students' most frequent challenges were related to providing evidence with examples and research to strengthen the essay's position in supporting the writer's statement [8].

Moreover, Kaur further support students to apprehend that writing an argumentative essay is considered challenging, complex, and complicated writing. It due to students' feel to set enough force when provided with an argumentative essay writing [12]. Students also have to settle coherent and logical arguments based on facts and they need strong opinion in their writing. Therefore, these studies imply that writing argumentative essay has become a significant problem for students, especially in the language department, not only in Indonesia but also in other countries. Considering the students' difficulties in writing an argumentative essay, it was necessary to be studied and discussed.

\section{METHODS}

The design of this research was descriptive qualitative research. A descriptive research is a design of research to describe a phenomenon and its characteristics that are more concerned with what has happened [13]. This design presented quantitative data collection preceded qualitative data collection. However, this research finding prioritized qualitative results this res while the quantitative findings shed light 
on the qualitative data to deepen the understanding of the results. This research data was students' scores in writing an argumentative essay from the final test of essay writing subject written by 25 students in the third semester of the English language and Literature Department at Universitas Negeri Padang in the academic year 2020/2021. The research instruments were a document checklist adapted by Reinking \& Osten (2017) and a holistic scoring rubric from TASC (Test of Scoring Guidance for the Argumentative Essay, 2016). It used to collect the data deal with the ability of students in writing based on the generic of argumentative essay.

\section{RESULTS AND DISCUSSIONS}

The finding of this study showed how the students' ability to write an argumentative essay proposed by Reinking and Osten's theory. Then, the ability is categorized into five-level: very poor, poor, average, good, and excellent. The result of this study indicated that students' ability to write an argumentative essay was categorized as moderate (average), with percentage $68 \%$. Table 1 displays the scores of the student's ability to write an argumentative essay that classified into some categories, percentage and students' scores are presented below:

Table 1. The Students' Ability in Writing Argumentative Essay

\begin{tabular}{|c|c|c|c|}
\hline Score & Category & Frequency & $\begin{array}{c}\text { Percentage } \\
(\boldsymbol{\%})\end{array}$ \\
\hline $27-32$ & Excellent & 2 & $8 \%$ \\
\hline $21-26$ & Good & 2 & $8 \%$ \\
\hline $14-20$ & Average & 17 & $68 \%$ \\
\hline $7-13$ & Poor & 3 & $12 \%$ \\
\hline $0-6$ & Very poor & 1 & $4 \%$ \\
\hline Total & & $\mathbf{2 5}$ & $\mathbf{1 0 0 \%}$ \\
\hline
\end{tabular}

The table above showed that students' ability to write argumentative essays is categorized average level with $68 \%$. The lowest score was 4 , while the highest score was 32 . The table displays that two students who scored between $27-32$ were in the category as excellent. Then, two students were in the category as good which the range of score among $21-26$. Next, seventeen students who got a score of 14- 20 were in the category as average. After that, three students were in the poor level, which the range score was $41-70$. The last, one student scored $0-6$, as a very poor category.

Afterward, the result was analyzed based on three indicators: introduction, body, and conclusion.

The explanations of the example of an argumentative essay are described in the following table:Weird Teens: Thrifting

Do you realize that there are many thrift shops nowadays? What is it anyway? So, a thrift shop is a store that sells prelove kinds of stuff. You can say that you are buying clothes that have been used before. It sounds gross, but it is the trend now. Thrift goods are cheap and unique, but they are dirty, and you will barely find the right size.

The main reason for thrifting is; they are cheap. Who doesn't like anything cheap? So, because thrift goods are secondhand, it makes the price go below the bar. You can afford new clothes even if you are broke. You can save much more money than buying a new one. Let's imagine one day you see a nice floral outer at Zara that is worth a value of Rp300.000, and the next day you see the exact same outer at a thrift shop for Rp100.000, although it has been used a few times before. Which one will you choose?

Another reason is thrift goods are quite unique. The thrift shop only sells one per clothes because it is preloved. They don't have stock of it. You also can find a lot of old-school or vintage kinds of stuff that rarely wear by people. You don't have to feel ashamed; like when you meet another person who wears the same clothing as you.

Everything has its own pros and cons, as well as thrifting. You know, thrift goods are dirty. Have you ever thought about the reason why the previous owner sells the clothes? It was because the clothes have some defect. The defect can be a stain or rip on some part. Also, you don't know who the previous owner was. They may have an infectious skin disease. You can get contracted if you use those clothes. It is not worth the price at all.

Another reason is you will barely find the right size. The size can be too small or too big. Because the store only sells one kind of clothes, it is kind of hard to find your size. Let's say that you buy a bigger size than yours. You have to rent a tailor to fix the size. What is that mean? Right, you have to pay more money.

In conclusion, the thrift shop can help you save your money while buying new clothes and it is kind of unique. However, it is also dirty and hard to find your size.

Based on the example of the argumentative essay above, it can be analysed as following indicators:

First indicator was introduction. They were posing some direct or indirect question and stating the position to be argued. The examples can be seen in the following table:

Table.2 Students' Example in Writing Introduction
\begin{tabular}{|l|l|}
\hline Introduction & \multicolumn{1}{c|}{ Example } \\
\hline $\begin{array}{l}\text { Poses some } \\
\text { direct or } \\
\text { indirect } \\
\text { question }\end{array}$ & $\begin{array}{l}\text { Do you realize that there are many } \\
\text { thrift shops nowadays? What is it } \\
\text { anyway? }\end{array}$ \\
\hline $\begin{array}{l}\text { States the } \\
\text { position to be } \\
\text { argued }\end{array}$ & $\begin{array}{l}\text { Although thrift goods are cheap and } \\
\text { unique, they are dirty, and you will } \\
\text { barely find the right size. } \\
\text { Thrift goods are cheap and unique, } \\
\text { but they are dirty, and you will } \\
\text { barely find the right size. }\end{array}$ \\
\hline
\end{tabular}


Second indicator was body. They were providing supporting evidence, explaining how the evidence was gathered that makes it credible, and indicating how evidence supports the conclusion.

Table.3 Students' Example in Writing Body

\begin{tabular}{|l|l|}
\hline Body & \multicolumn{1}{|c|}{ Example } \\
\hline $\begin{array}{l}\text { Provides } \\
\text { supporting } \\
\text { evidence }\end{array}$ & $\begin{array}{l}\text { The main reason for thrifting } \\
\text { is; they are cheap. }\end{array}$ \\
\hline $\begin{array}{l}\text { Explains how the } \\
\text { evidence was } \\
\text { gathered that } \\
\text { makes it credible }\end{array}$ & $\begin{array}{l}\text { So, because thrift goods are } \\
\text { secondhand, it makes the price } \\
\text { go below the bar. } \\
\text { Thrift goods are quite unique. } \\
\text { Thrift shop only sells one per } \\
\text { clothes because it is preloved. } \\
\text { Thrift goods are dirty }\end{array}$ \\
\hline $\begin{array}{l}\text { Indicates how the } \\
\text { evidence supports } \\
\text { the conclusion }\end{array}$ & $\begin{array}{l}\text { Everything has its own pros } \\
\text { and cons, as well as thrifting. }\end{array}$ \\
\hline
\end{tabular}

The last indicator was conclusion. They were reaffirming the writers' position, suggesting the consequence of the position, and raising a general question, evaluating the evidence and coming to a conclusion.

Table.4 Students' Example in Writing Conclusion

\begin{tabular}{|l|l|}
\hline \multicolumn{1}{|c|}{ Conclusion } & \multicolumn{1}{|c|}{ Example } \\
\hline $\begin{array}{l}\text { Reaffirms the } \\
\text { writers' position }\end{array}$ & $\begin{array}{l}\text { The thrift shop can help you } \\
\text { save your money }\end{array}$ \\
\hline $\begin{array}{l}\text { Suggests the } \\
\text { consequence of } \\
\text { the position }\end{array}$ & $\begin{array}{l}\text { The thrift shop can help you } \\
\text { save your money while buying } \\
\text { new clothes and it is kind of } \\
\text { unique with low price. }\end{array}$ \\
\hline $\begin{array}{l}\text { Raises a general } \\
\text { question, } \\
\text { evaluates the } \\
\text { evidence and } \\
\text { comes to a } \\
\text { conclusion also dirty and hard to find } \\
\text { your size. }\end{array}$ \\
\hline \multicolumn{1}{|l}{} \\
\hline
\end{tabular}

Based on the findings above revealed that the analysed of students' argumentative essay ability in average level. It proved that the students can write an argumentative essay based the indicators needed. However, it cannot be judged that this low ability occurs only because the faults in learning process. Considering some students' difficulties in writing argumentative essay, it can be conclude that the difficulties that students have is not only in the form of how they structure their voice in the essay, but also the difficulties faced by the students involve the content knowledge that they have, the lack of evidence in their essay, the lack of criticality or analysis, and the lack of related information within the essay. Therefore, the students demand more practice, instruction and then receive feedback from the lectures to improve their ability, particularly in writing an argumentative essay.

\section{CONCLUSION}

This study found that the students' ability to write an argumentative essay was average at $68 \%$. The result of students' scores presented in the previous section implied that the students needed more practice and developed their ability to write an argumentative essay correctly. Then, in writing an argumentative essay, some students do not follow the indicators of writing an essay completely. Thus, the researcher hopes that students get more practice, instruction, and feedback from the lectures to improve their ability, especially in writing an argumentative essay. Besides, the students need to read more references to make it easier to develop an argumentative essay with more robust and more interesting arguments to support their thesis. Then, the lecturers should encourage the students to enrich their vocabulary knowledge.

\section{ACKNOWLEDGMENTS}

In the beginning, I would like to convey my deepest gratitude to Allah SWT for his blessing and mercies. Because of him, the researcher can entirely conduct this research paper. Then, I would like to thank the advisor Dr. Muhammad Al Hafizh, S.S., M.A., for the advice, motivation, and guidance while writing this research. Next, the researcher would like to thank the lecturer and students in the third semester of the English language and Literature Department at Universitas Negeri Padang for collaborating and supporting the study.

\section{REFERENCES}

[1] D. Thi and N. Anh, "EFL Student's Writing Skills : Challenges and Remedies," vol. 9, no. 6, pp. 74-84, 2019, doi: 10.9790/7388-0906017484.

[2] S. Ren, Y. Cao, Y. Gao, and Q. Li, "Thematic Operational Approach and the Writing Teaching of College English," Asian Soc. Sci., vol. 5, no. 11, pp. 141-146, 2009, doi: 10.5539/ass.v5n11p141.

[3] I. M. Alfaki, "University students' English writing problems," Int. J. English Lang. Teaching. Publ. by Eur. Cent. Res. Train. Dev. UK, vol. 3, no. 3, pp. 40-52, 2015, [Online]. Available: http://www.eajournals.org/wpcontent/uploads/University-Students----EnglishWriting-Problems-Diagnosis-and-Remedy.pdf.

[4] E. Nurbayani, "The Ability of Indonesian EFL Learners in Writing Academic Papers," vol. 17, no. 2, pp. 237-250, 2017.

[5] D. H. Brown, Teaching by Principles: An Interactive Approach to Language Pedagogy, Second. White Plains, New York: Pearson Education., 2001.

[6] R. Murray and S. Moore, The handbook of academic writing: a fresh approach, First., vol. 1. New York: Open University Press, 2006.

[7] A. Oshima and A. Hogue, Writing Academic English, 4th ed. New York: Pearson Education., 2006. 
[8] R. Permata, "Students' Ability in Developing the Paragraphs of Argumentative Essay," vol. 8, no. 7, pp. 892-895, 2019.

[9] J. A. Reinking and R. von der Osten, Strategies for Successful Writing, vol. 38, no. 2. United States: Pearson, 2017.

[10] M. Ka-kan-dee and S. Kaur, Teaching Strategies Used by Thai EFL Lecturers to Teach Argumentative Writing, vol. 208, no. Icllic 2014. Elsevier B.V., 2015.

[11] J. Peloghitis, "Difficulties and strategies in argumentative writing: A qualitative analysis review of the literature," Transform. Lang. Educ., pp. 399-406, 2016.

[12] A. Kaur, J. Singh, R. Nor, and S. Raja, "EDUVELOP Peer Instruction in a Flipped Learning Environment: Investigating ESL Students ' Critical Thinking Performance in Argumentative Essay Writing," vol. 4, no. 2, pp. 51-70, 2021.

[13] W. R. Gall, M.D., Gall, J.P., \& Borg, Educational research: An introduction, 8 ed. Boston: Pearson, 2007. 